\title{
APENDICITIS AGUDA IZQUIERDA; UNA PRESENTACIÓN POCO HABITUAL DE UNA PATOLOGÍA MUY COMÚN EN LA POBLACIÓN ECUATORIANA. REVISIÓN BIBLIOGRÁFICA Y REPORTE DE UN CASO.
}

Orbea Marcial Víctor ${ }^{1}$, Villagrán Morales Sthefany ${ }^{1 *}$, Albuja Díaz Lizeth ${ }^{1}$, Ibarra Guamán Lorena ${ }^{1}$.

DOI: $10.48018 /$ rmv.v32.i1.S7

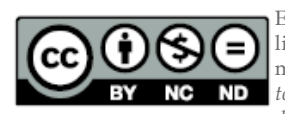

ste artículo está bajo una icencia de Creative Comnons de tipo Reconocimiento - No comercial - Sin obras OPEN ACCESS derivadas 4.0 International.

1. Hospital General Docente Ambato. Médico del Servicio de Cirugía General. Ambato, Ecuador.

ORCID ID:

Orbea Marcial Víctor

orcid.org/0000-0002-1543-8422

Villagrán Morales Sthefany

orcid.org/0000-0002-3545-0787

Albuja Díaz Lizeth

orcid.org/0000-0001-7516-9669

Ibarra Guamán Lorena

orcid.org/0000-0002-9505-4487

* Corresponding author:

Villagrán Morales Sthefany

E-mail: donaabigail@hotmail.com

Article history: Manuscript presented at the I Clinical Case Contest - Hospital Vozandes Quito, February 27, 2021

CARE 2017 Check List statement: The authors have real the CARE 2017 Check List and the manuscript was prepared and revised according to the CARE 2017 Checklist.

Conflict of interest: All authors declared that there are no conflicts of interest.

Financial disclosure: The authors have no financial relationships relevant to this article to disclose.

Forma de citar este artículo: Orbea MV, Villagrán S, Albuja L, Ibarra L. APENDICITIS AGUDA IZQUIERDA; UNA PRESENTACIÓN POCO HABITUAL DE UNA PATOLOGÍA MUY COMÚN EN LA POBLACIÓN ECUATORIANA. REVISIÓN BIBLIOGRÁFICA Y REPORTE DE UN

CASO. Rev Med Vozandes. 2021; 32 (1 Suppl 1): S13-S14

\section{Resumen}

Introducción: La apendicitis aguda es una de las patologías quirúrgicas urgentes más común en la población ecuatoriana, y la presentación atípica del apéndice en el lado izquierdo se presenta como un reto diagnóstico, ya que se observa con mayor frecuencia en anomalías congénitas como la malrotación del intestino medio, trastorno poco común con una incidencia de uno de cada 10,000 individuos.

Descripción del Caso: Descripción del caso: Presentamos el caso clínico de una niña de 8 años de edad sin antecedentes patológicos de importancia, ingresada en el servicio de Pediatría con un cuadro de dolor abdominal localizado en hemiabdomen izquierdo, de 48 horas de evolución, acompañado de náuseas, vómitos, distensión abdominal y alza térmica; abdomen doloroso a la palpación en flanco y fosa iliaca izquierda, signo de Mussy positivo. La paciente presentó leucocitosis y neutrofilia; en los exámenes de imagen se advirtió un engrosamiento de la grasa mesentérica a nivel de fosa iliaca izquierda y niveles hidroaéreos a desnivel del marco colónico. Fue intervenida quirúrgicamente y los hallazgos fueron un plastrón apendicular conformado por un apéndice perforada en el tercio distal y base apendicular indemne, epiplón y tercio distal del colon descendente; su evolución postquirúrgica fue favorable.

Conclusión: La apendicitis aguda puede presentarse con síntomas atípicos debido a ubicaciones inusuales del apéndice, una de las presentaciones poco habituales puede presentarse en la malrotación. La mayoría de los casos son asintomáticos hasta el desarrollo de complicaciones agudas y requieren imágenes para el diagnóstico, convirtiéndose en un reto al definir el tratamiento adecuado y oportuno. 
Keywords: Appendicitis, acute, left, intestinal, mal-

\section{Abstract}

LEFT ACUTE APPENDICITIS; AN UNUSUAL PRESENTATION OF A VERY COMMON PATHOLOGY IN THE ECUADORIAN POPULATION. BIBLIOGRAPHIC REVIEW AND REPORT OF A CASE. rotation.

Introduction: Acute appendicitis is one of the most common urgent surgical pathologies in the Ecuadorian population, and the atypical presentation of the appendix on the left side is presented as a diagnostic challenge, since it is observed more frequently in congenital anomalies such as malrotation of the midgut, a rare disorder with an incidence of one in 10,000 individuals.

Case description: We present the clinical case of an 8-year-old girl with no significant pathological history, admitted to the Pediatrics service with a 48-hour history of abdominal pain located in the left hemiabdomen, accompanied by nausea, vomiting, abdominal distention and thermal rise; tender abdomen on palpation in the flank and left iliac fossa, positive Mussy's sign. The patient presented with leukocytosis and neutrophilia; imaging examinations revealed thickening of the mesenteric fat at the level of the left iliac fossa and air-fluid levels at an elevation of the colonic framework. She underwent surgery and the findings were an appendicular plastron made up of a perforated appendix in the distal third and undamaged appendicular base, omentum and distal third of the descending colon; her postsurgical evolution was favorable.

Conclusion: Acute appendicitis can present with atypical symptoms due to unusual locations of the appendix, one of the unusual presentations can present in malrotation. Most cases are asymptomatic until the development of acute complications and require imaging for diagnosis, becoming a challenge when defining the appropriate and timely treatment. 